\title{
Influence of plankton community structure on the contribution of bacterial production to metazooplankton in a coastal mesocosm
}

\author{
Hiroshi Koshikawa ${ }^{1, *}$, Shigeki Harada ${ }^{1}$, Masataka Watanabe ${ }^{1}$, \\ Kazuhiro Kogure ${ }^{2}$, Teru Ioriya ${ }^{3}$, Kunio Kohata ${ }^{1}$, Toshihiko Kimura ${ }^{1}$, \\ Kazumi Sato ${ }^{4}$, Takashi Akehata ${ }^{4}$ \\ 'National Institute for Environmental Studies, 16-2 Onogawa, Tsukuba, Ibaraki 305-0053, Japan \\ ${ }^{2}$ Ocean Research Institute, University of Tokyo, 1-15-1, Minamidai, Nakano-ku, Tokyo 164-8639, Japan \\ ${ }^{3}$ Laboralory of Phycology, Tokyo University of Fisheries, 4-5-7 Konan, Minato-ku, Tokyo 108-8477, Japan \\ ${ }^{4}$ Department of Industrial Chemistry, Science University of Tokyo, 1-3 Kagurazaka, Shinjuku-ku, Tokyo 162-0825, Japan
}

\begin{abstract}
To understand energy passing from bacterial production to metazooplankton in an aquatic ecosystem, the relative significance of bacterial and photosynthetic production as carbon sources for metazooplankton was determined in a $14 \mathrm{~d}$ coastal mesocosm experiment, using frequent in situ batch incubations with dissolved organic and inorganic ${ }^{13} \mathrm{C}$ tracers. The contribution ratio (CR) of bacterial to photosynthetic production as metazooplankton food resources fluctuated from 6 to $41 \%$, according to successional changes in the plankton community structure in the mesocosm. The lowest CR $(6 \%)$ occurred when nano-sized autotrophs were highly abundant and appendicularians Oikopleura sp., which are capable of ingesting only pico- to nano-sized particles, increased rapidly. After these small autotrophs disappeared, the CR increased to $30-40 \%$, suggesting that the appendicularians were supported largely by bacterial production at that time. When the metazooplankton consisted mainly of copepods, the CR reached about $10 \%$ despite the relatively low ratio (ca $15 \%$ ) of net bacterial community production to photosynthesis; also, the copepods would have been able to exploit bacterial production only through intermediaries such as bacterivorous protists. In this period with copepods dominant, Gymnodinium mikimotoi was the dominant autotroph and might have been a main source of prey for grazers. However, copepods avoid this dinoflagellate, as often reported. Consequently, not much of the autotrophic production of the dinoflagellate might have been ingested by the copepods. We conducted that nano-sized autotrophs and herbivorous protists were likely to be the main suppliers of photosynthetic production for copepods, as nano-sized bacterivores were the suppliers of bacterial production. These findings suggest that bacterial production and the carbon pathway, i.e. a microbial loop, are not always the terminus of organic carbon flow in food webs, but can be an integral component of the food pool for metazooplankton in the coastal environment.
\end{abstract}

KEY WORDS: Microbial loop $\cdot$ Appendicularians $\cdot$ Copepods $\cdot$ Mesocosm

\section{INTRODUCTION}

Since the concept of the microbial loop in aquatic ecosystems was suggested (Azam et al. 1983), there has been much discussion about the fate of bacterial production, which amounts to $20-30 \%$ of photosynthetic production (Cole et al. 1988). Nowadays, it is often accepted that the microbial loop is mainly

·E-mail: koshikaw@nies.go.jp involved as a respiratory carbon sink (e.g. Sanders \& Wickham 1993) because of the numerous trophic levels involved (e.g. Wikner \& Hagström 1988). It is, hence, theoretically possible that only a small portion of production by bacterioplankton eventually reaches higher trophic levels, and this has been demonstrated experimentally (e.g. Ducklow et al. 1986). In this view, bacterial production contributes little to the food resources of metazooplankton, in particular when a classical food chain (e.g. diatoms $\rightarrow$ copepods) is predominant. How- 
ever, it has been reported that copepods often prefer nano- and micro-sized planktonic protists, which are members of the microbial loop, over phytoplankton (e.g. Stoecker \& Capuzzo 1990), and that a significant proportion of the copepods' diet comes from these protists (e.g. Gifford \& Dagg 1991); also, some gelatinous zooplankton (e.g appendicularians) are capable of ingesting bacteria-sized particles directly (e.g. Alldredge \& Madin 1982), which may form an energyefficient, short-circuiting pathway. It has also been stated that protists often consume mainly phytoplankton (e.g. see review by Sherr \& Sherr 1994). It may be concluded that the carbon pathways of bacterial and primary production are similarly complex and may be both carbon sinks, as mentioned by Sherr \& Sherr (1988), within the concept of the microbial food web. However, it is still uncertain whether or not bacterial production can supply food for metazooplankton and what proportion of the metazooplankton diet is supplied by bacterial versus photosynthetic production in aquatic ecosystems

One simple approach to clarify the issue is to compare simultaneously the carbon flow from bacterial and photosynthetic production to metazooplankton. To date, only Wylie \& Currie (1991) and our previous study (Koshikawa et al. 1996) have used this approach. Both studies showed that the percentages of algal or heterotrophic bacterial carbon transferred to metazooplankton per unit time were of a similar magnitude in freshwater and marine systems. These studies suggested strongly that metazooplankton can be supported by both bacteria and algae, depending on their biomass or production. In addition, Wylie \& Currie (1991) tried to analyze the relative significance of bacteria and algae for metazooplankton using a compartmental ecosystem model. They suggested that considerable carbon input to metazooplankton (16 to $21 \%$ ) originated from bacteria and autotrophic picoplankton when cladocerans were dominant, but that this input was insignificant when copepods were dominant. However, their analysis depended on many assumptions, such as the definition of number of trophic compartments and the structure of their model. Our previous study also showed that the availability of bacterial production for metazooplankton was quite different between copepod- and doliolid-dominant systems, suggesting that transfer efficiency of bacterial carbon to metazooplankton was strongly affected by the metazooplankton species. However, we did not discuss in detail trophic interactions that included protists.

The present study aimed to determine the relative contribution for metazooplankton food resources of bacterial versus photosynthetic production, by quantitative comparison of the carbon flow from both dissolved organic and inorganic carbon to metazooplank- ton per unit time, using short-term ( $4 \mathrm{~h}$ ) in situ bottle incubation experiments with D-[U-6- $\left.{ }^{13} \mathrm{C}\right]$ glucose or $\mathrm{NaH}\left[{ }^{13} \mathrm{C}_{3} \mathrm{O}_{3}\right.$. Carbon flow was defined as the product of net community production and the percentage of ${ }^{13} \mathrm{C}$, originally taken up by bacterioplankton or autotrophs, transferred to metazooplankton during incubation. We also aimed to demonstrate how bacterial contribution was controlled by changes in the plankton community structure, i.e. trophic interactions from picoplankton to metazooplankton.

The ${ }^{13} \mathrm{C}$ tracer experiments were done every few days within a coastal enclosed mesocosm (Watanabe et al. 1995) over a 2 wk period, which enabled us to observe rapid succession in the plankton community. Here we discuss the continuous changes in the contribution of bacterial versus photosynthetic production to metazooplankton, according to the changes in abundance and species of plankton in the mesocosm.

\section{MATERIALS AND METHODS}

Experimental conditions. A marine mesocosm $15 \mathrm{~m}$ in diameter and 16 to $17 \mathrm{~m}$ deep, ca $320 \mathrm{~m}^{3}$ in volume; see Watanabe et al. 1995 for details) was deployed in a cove off the Ieshima Islands in the Seto Inland Sea Japan, from 30 July (Day 0) to 12 August (Day 13) 1994 A vertical circulation system was installed, which provided a well-mixed surface layer ( 0 to $5 \mathrm{~m}$ in depth) and prevented immobile species such as diatoms from sinking rapidly (Watanabe et al. 1995). Macronutrients (nitrate, phosphate, and silicate) were added at Day 0 in order to promote a succession of plankton species. Seawater temperature, salinity, $\mathrm{pH}$ and oxygen concentration at depths of $0,1,2.5$ and $5 \mathrm{~m}$ were measured (Surveyer II, Hydrolab. Co.) every morning at 09:00 h. Seawater samples were collected using a silicon-tube sampling system (for chl $a$, nutrient analyses and phytoplankton species determination) and a $10 \mathrm{l}$ Van Dorn sampler (for tracer experiments, enumeration of bacteria, protozoans and metazoans) from depths of $0.5,2.5$ and $5 \mathrm{~m}$ between 09:00 and 10:00 h during the experiment period. The samples $(0.5$ to 1 l) for chl a (Shimadzu HPLC system, Kohata et al. 1991) and nutrient analyses (Technicon AutoAnalyzer) were filtered with precombusted Whatman GF/F glass fiber filters $\left(450^{\circ} \mathrm{C}\right.$ for $\left.4 \mathrm{~h}\right)$. The filters with chl $a$ and filtrates for nutrient measurements were stored at $-20^{\circ} \mathrm{C}$. These sampling and analytical methods have been described in more detail by Watanabe et al. (1995).

Plankton enumeration. Phytoplankton samples were fixed with 6 to $10 \%$ formalin, and the species composition, abundance, volumes (equivalent spherical diameters-ESD) were determined by microscopy. Samples for pico- and nanoplankton, excluded from the phyto- 
plankton enumeration, were taken from a depth of $0.5 \mathrm{~m}$, fixed with glutaraldehyde (final conc. $1 \%$ ) and stored at $4^{\circ} \mathrm{C}$ until used for counts. Subsamples were stained with DAPI (final conc. $1 \mathrm{mg} \mathrm{m}^{-1}$; Porter \& Feig 1980 ) and then concentrated onto 0.2 or $0.8 \mu \mathrm{m}$ porosity black Nuclepore filters under gentle vacuum. The filters were analyzed for abundance of picoplankton (0.2 to $2 \mu \mathrm{m}$, autotrophic picoplankton [APP] and freeliving bacterioplankton), small nanoplankton ( 2 to $8 \mu \mathrm{m}$, autotrophic nanoflagellates [ANF] and non-fluorescing heterotrophic nanoflagellates [HNF]) and large nanoplankton ( 8 to $20 \mu \mathrm{m}$, non-fluorescing heterotrophic nanoflagellates and ciliates), using epifluorescence microscopy as described by Nakamura et al. (1995). Mixotrophic nanoflagellates were included with the ANF. Samples (10 l) for heterotrophic protists (>20 $\mu \mathrm{m}$ ) and metazooplankton were taken from depths of 0.5 and $5 \mathrm{~m}$ and passed through 100 and $20 \mu \mathrm{m}$ plankton nets sequentially; these samples were fixed with 6 to $10 \%$ formalin and stored in a dark, cool place. Light microscopy was used to determine the abundance and species composition of the 20 to $100 \mu \mathrm{m}$ and $>100 \mu \mathrm{m}$ size classes.

Short-term in situ incubation experiments. ${ }^{13} \mathrm{C}$ tracer experiments were conducted to follow the transfer of labeled carbon from heterotrophic and autotrophic producers to metazooplankton (Koshikawa et al. 1996). As a tracer to measure the bacterial carbon. pathway, D-[U-6- $\left.{ }^{13} \mathrm{C}\right]$ glucose (ca $5 \mathrm{mg} \mathrm{l}^{-1}$ ) was chosen, since this sugar occurs universally in seawater (Mopper et al. 1980) and is extensively utilized by marine bacteria (e.g. Azam \& Hodson 1977). For measurement of the photosynthetic carbon pathway, $\mathrm{NaH}\left[{ }^{13} \mathrm{C}\right] \mathrm{O}_{3}$ ( $\mathrm{ca}$ $20 \mathrm{mg} \mathrm{l}^{-1}$ ) was used. Seawater for the tracer experiment taken from a depth of $0.5 \mathrm{~m}$ in the mesocosm was transferred to an acid-cleaned 4.51 clear polycarbonate bottle and the relevant organic or inorganic ${ }^{13} \mathrm{C}$ tracer was added. The bottle was then suspended for $4 \mathrm{~h}(09: 30 \mathrm{~h}$ to $13: 30 \mathrm{~h})$ at the depth from which the seawater had been collected $(0.5 \mathrm{~m})$. The in situ incubated sample was fractionated by sequential filtration using plankton nets (100 and $20 \mu \mathrm{m}$ mesh), a precombusted Whatman GF/F (ca $0.7 \mu \mathrm{m}$ pore size) filter and a precombusted Whatman Anodisc aluminum oxide filter (0.2 $\mu \mathrm{m}$ pore size), which allows greater retention of bacterioplankton (Altabet 1990). The samples on the plankton nets were washed with filtered seawater $(\mathrm{GF} / \mathrm{F})$ to remove particles smaller than the respective mesh sizes and then collected on precombusted Whatman GF/C filters. In order to determine the natural carbon isotope ratio of particles at the starting point of each incubation, the original seawater was also filtered with GF/F filters. The 5 and 6 in situ incubations for bacterial and photosynthetic pathways were carried out on Days 2, 4, 6, 8 and 10 and Days 1, 3, 5, 7,9 and
11 , respectively. All filter samples were stored at $-20^{\circ} \mathrm{C}$ until analysis. POC and ${ }^{13} \mathrm{C}$ abundance (atom \%) were determined using a system comprised of an elemental analyzer (EA1108, Fisons) and an isotope-ratio mass spectrometer (MAT252, Finnigan MAT) (Thompson \& Calvert 1994).

We tested the possibility that the addition of the high concentration of D-[U-6- ${ }^{13}$ C]glucose $\left(5 \mathrm{mg} \mathrm{l}^{-1}\right)$ influenced bacterial production over several hours. Each experimental day, the sample collected, together with that for the in situ incubation, was pre-screened with a Nuclepore filter $(2 \mu \mathrm{m})$ and incubated with and without glucose $\left(5\right.$ and $\left.0 \mathrm{mg}^{-1}\right)$ for $6 \mathrm{~h}$. Before and after each incubation, subsamples were fixed with glutaraldehyde, and the increment of total bacterial biovolume per unit sample volume ( $\Delta$ biovolume) in each incubation was determined by image-analyzed fluorescence microscopy (see below; 'Net bacterial community production'). These sub-experiments, with and without glucose, did not show significant differences in apparent $\Delta$ biovolume $\left(\mu^{3} \mathrm{ml}^{-1} 6 \mathrm{~h}^{-1}\right)$. It was assumed that the enriched glucose would be used as an alternative to the labile dissolved organic substrate in our eutrophic mesocosm environment. Hence, it was also assumed that D-[U-6- ${ }^{13} \mathrm{C} / g l u c o s e$ addition did not greatly influence the amounts of bacterial carbon transfer through the plankton community in the in situ incubation bottles.

In the case of incubation with high concentrations of labeled glucose and bicarbonate, uni-directional transfer of the labels from producers to higher trophic consumers would be dominant (i.e. bacteria $\rightarrow$ bacterivores $\rightarrow$ [higher order heterotrophic protists] $\rightarrow$ metazooplankton, and autotrophs $\rightarrow$ [herbivorous protists] $\rightarrow$ metazooplankton). A proportion of the added label carried in one carbon pathway might be carried to the other pathway through various biological activities (e.g. DOC exudation by phytoplankton). However, such transport of label would be small enough to be excluded from measurement of uni-directional label transfers in trophic carbon pathways under our experimental conditions (Koshikawa et al. 1996).

PLT calculation. The net label transformation from dissolved to particulate carbon for each size fraction was calculated as the excess ${ }^{13} \mathrm{C}\left(\mu \mathrm{g}^{13} \mathrm{C} \mathrm{l}^{-1} 4 \mathrm{~h}^{-1}\right)$ against natural carbon isotope abundance (Eq. 1).

$$
{ }^{13} \mathrm{C}_{\mathrm{ex}}=\left(\mathrm{a}_{\mathrm{s}}-\mathrm{a}_{\mathrm{n}}\right) \times \mathrm{POC}
$$

where $a_{s}$ and $a_{n}$ are the ${ }^{13} \mathrm{C}$ atom $\%$ in an incubated sample in a given size fraction, and in a natural sample, respectively, and POC $\left(\mathrm{mg} \mathrm{l}^{-1}\right)$ is the particulate organic carbon in a given size fraction. The $>100 \mu \mathrm{m}$ fraction would comprise mostly the metazooplankton assemblage. Contamination by attached or flocculated bacteria on the $>100 \mu \mathrm{m}$ particles was assumed to be 
relatively insignificant (Koshikawa et al. 1996). Contamination by some large-sized or chain-forming phytoplankton on the $>100 \mu \mathrm{m}$ faction was also assumed to be insignificant. The possible overestimate due to such phytoplankton retention was about $15 \%$ of ${ }^{13} \mathrm{C}$ determination on the $>100 \mu \mathrm{m}$ fraction. This was calculated as the difference in both the incorporated ${ }^{13} \mathrm{C}$ and chl a concentrations between total particles and those retained on the $>100 \mu \mathrm{m}$ fraction. Physical adsorption blanks of labeled carbon onto particulate materials, which were estimated separately by means of a glutaraldehyde-killed incubation system, were negligible. The ${ }^{13} \mathrm{C}$ label incorporation on the $>100 \mu \mathrm{m}$ fraction was therefore assumed to come mainly from labeled carbon ingestion by metazooplankton.

To determine the relative significance of carbon transfer to metazooplankton through bacteria and autotrophs, the percentage of label transfer (PLT\%) to the $>100 \mu \mathrm{m}$ fraction $\left({ }^{13} \mathrm{C}_{e x,>100 \mu \mathrm{m}}\right)$ in the total transfer to all fractions $\left({ }^{13} \mathrm{C}_{\mathrm{ex}, \mathrm{all}}\right)$ was first calculated (Eq. 2).

$$
\text { PLT }=\left(\frac{{ }^{13} \mathrm{C}_{\text {ex, }}>100 \mu \mathrm{m}}{{ }^{13} \mathrm{C}_{\text {ex,all }}}\right) \times 100
$$

The PLT represents the proportion of carbon fixed by bacterioplankton or autotrophs and conserved as a part of the particles that may be transferred to metazooplankton by their feeding activities during the $4 \mathrm{~h}$ incubation, although a proportion of the fixed ${ }^{13} \mathrm{C}$ label will be respired by the producers themselves and by some intermediaries such as heterotrophic protists. The PLT is an incubation time-dependent value but can be an index of the degree of ease with which carbon passes through the trophic levels to metazooplankton (Koshikawa et al. 1996).

CR calculation. The product of PLT (\%) and the bacterial or photosynthetic production over $4 \mathrm{~h}\left(\mathrm{BP}_{4 \mathrm{~h}}\right.$ or $\mathrm{PP}_{4 \mathrm{~h}}$ ) indicates the amount of dissolved organic or inorganic carbon transfer to metazooplankton size fractions (DOC Metazoo $_{\text {or }}$ DIC $_{\text {Metazoo }}$ ) via the bacterial or photosynthetic pathway during the in situ incubation time (Eq. 3). Since some respiration losses occur during ${ }^{13} \mathrm{C}$ transfer to metazooplankton during incubation, $\mathrm{BP}_{4 \mathrm{~h}}$ and $\mathrm{PP}_{4 \mathrm{~h}}$ for calculating $\mathrm{DOC}_{\text {Metazoo }}$ and DIC Metazoo with the PLTs should be determined as net production, i.e. the quantities of produced and conserved particles in the food web. We defined these as 'net community production'. The methods for determining $\mathrm{BP}_{4 \mathrm{~h}}$ and $\mathrm{PP}_{4 \mathrm{~h}}$ are described later.

$$
\begin{aligned}
& \mathrm{DOC}_{\text {Metazoo }}=\mathrm{BP}_{4 \mathrm{~h}} \times(\mathrm{PLT} \times 0.01) \\
& \mathrm{DIC}_{\text {Metazoo }}=\mathrm{PP}_{4 \mathrm{~h}} \times(\mathrm{PLT} \times 0.01)
\end{aligned}
$$

The ratio of $\mathrm{DOC}_{\text {Metazoo }}$ to $\mathrm{DIC}_{\text {Metazoo }}$ gives the relative contribution of bacterial and photosynthetic production as carbon resources for metazooplankton: CR
(\%) (contribution ratio) (Eq. 4). The CR is a more direct and quantitative value than PLT for the analysis of relative carbon contribution.

$$
\mathrm{CR}=\frac{\mathrm{DOC}_{\text {Metazoo }}}{\mathrm{DIC}_{\text {Metazoo }}} \times 100
$$

Net photosynthetic community production. Net photosynthetic community production rate for $4 \mathrm{~h}$ $\left(\mathrm{PP}_{4 \mathrm{~h}}\right)\left(\mu \mathrm{g} \mathrm{C} \mathrm{l}^{-1} 4 \mathrm{~h}^{-1}\right)$ was estimated by summation of the carbon transformation rate from DIC to particles in each size fraction; the calculation was based on the ${ }^{13} \mathrm{C}$ method of Hama et al. (1983) for the in situ incubation experiments, following label transfer in the photosynthetic carbon pathway conducted on Days $1,3,5,7,9$ and 11 .

Net bacterial community production. Bacterioplankton assemblages use various dissolved organic compounds as carbon sources, and these compounds may have been consumed through different biochemical processes and at different rates by different species in the bacterial carbon pathway. In this study, how ever, we assumed that fixed natural DOC and fixed ${ }^{13} \mathrm{C}$ derived from the enriched glucose by bacterioplankton would be consumed at similar rates of loss in the mesocosm, because glucose is extensively used by bacterioplankton in coastal environments. On this assumption, we determined the net bacterial community production as follows.

Together with in situ incubation using $\mathrm{D}-[\mathrm{U}-6$ ${ }^{13} \mathrm{C}$ lglucose to follow the label transfer in the bacterial carbon pathway, we performed 2 batch incubations on Days 2, 4, 6, 8 and 10, using the same seawater taken from a depth of $0.5 \mathrm{~m}$ in the mesocosm. The seawater sample (ca 1 l) for the 2 incubations was passed through a $2 \mu \mathrm{m}$ Nuclepore filter. A subsample of filtrate $(\mathrm{ca} 500 \mathrm{ml})$ was incubated with $\mathrm{D}-\left[\mathrm{U}-6-{ }^{13} \mathrm{C}\right] \mathrm{glu}-$ cose $\left(5 \mathrm{mg} \mathrm{l}^{-1}\right)$ for $6 \mathrm{~h}$ at ambient temperature. Another subsample (ca $300 \mathrm{ml}$ ) was incubated without glucose in parallel. Prior to the incubation, other subsamples $(50 \mathrm{ml})$ were fixed with glutaraldehyde to measure the initial bacterial population density and biovolume. After incubation, a sample with $D-\left[\mathrm{U}-6-{ }^{13} \mathrm{C}\right]$ glucose $(\mathrm{ca}$ $300 \mathrm{ml}$ ) was filtered on a precombusted Whatman Anodisc filter $(0.2 \mathrm{\mu m})$ to determine glucose uptake ( $\left.\mu \mathrm{g}^{13} \mathrm{C}^{-1} \mathrm{~h}^{-1}\right)$, and a sample without glucose (ca $50 \mathrm{ml}$ ) was fixed with glutaraldehyde for measurement of the final bacterial density and biovolume. The fixed samples and filters were stored at 4 and $-20^{\circ} \mathrm{C}$, respectively. Uptake of ${ }^{13} \mathrm{C}$ glucose was determined by the system described above (see 'short-term in situ incubation experiments'). Bacterial density $\left(\mathrm{ml}^{-1}\right)$ and biovolume $\left(\mu \mathrm{m}^{3} \mathrm{ml}^{-1}\right)$ were determined using an image-analyzer epifluorescence microscopy system comprised of an Olympus BH-2 (magnification: $100 \times 5$; mirror unit: $440 \mathrm{~nm}$; band-pass filter $540 \mathrm{~nm}$ ), a Hamamatsu Pho- 
Table 1. Results of measurement of bacterial $\Delta$ biovolume (determined by image-analysis epifluorescence microscopy; SD determined by replicate analysis of single sample) and D$\left[\mathrm{U}-6-{ }^{13} \mathrm{C}\right]$ glucose uptake in the 3 incubation systems (see 'Materials and methods' for details)

\begin{tabular}{|lccc|}
\hline Day & $\begin{array}{c}\Delta \text { biovolume }_{2 \mu m} \\
\left(\times 10^{4} \mu \mathrm{m}^{3} \mathrm{ml}^{-1} \mathrm{~h}^{-1}\right)\end{array}$ & $\begin{array}{c}\text { Glu-uptake } \\
\left(\mu \mathrm{g}^{13} \mathrm{C}^{-1} \mathrm{~h}^{-1}\right)\end{array}$ & $\begin{array}{c}\text { Glu-uptake } \\
\left(\mu \mathrm{g}^{13} \mathrm{C} \mathrm{l}^{-1} \mathrm{~h}^{-1}\right)\end{array}$ \\
\hline 2 & $11 \pm 2.3$ & 7.5 & 1.6 \\
4 & $7.7 \pm 3.3$ & 9.6 & 2.5 \\
6 & $6.6 \pm 2.7$ & 6.9 & 2.7 \\
8 & $4.7 \pm 2.8$ & 6.2 & 4.4 \\
10 & $4.3 \pm 1.9$ & 7.1 & 4.0 \\
\hline
\end{tabular}

tonics C4271 SIT CCD camera and an Olympus XL500 TV image processor ( $512 \times 480$ pixels, 8 -bit-grayscale). Edge detection, image segmentation of bacterial cells and calibration were carried out by the methods of Viles \& Sieracki (1992) and Verity \& Sieracki (1993). Net bacterial community production $\left(\mathrm{BP}_{4 \mathrm{~h}}\right)\left(\mathrm{mg} \mathrm{Cl}^{-1} 4\right.$ $\mathrm{h}^{-1}$ ) was estimated using Eq. (5).

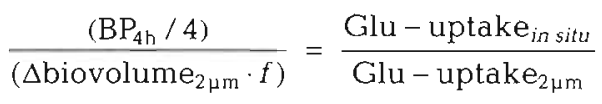

where, $\Delta$ biovolume $_{2 \mu \mathrm{m}}\left(\mathrm{\mu m}^{3} \mathrm{ml}^{-1} \mathrm{~h}^{-1}\right)$ is the increment of bacterial biovolume per unit time in the $2 \mu \mathrm{m}$ prescreened incubation without glucose, and $f$ is a conversion factor ( $\mathrm{pg} \mathrm{C} \mathrm{Cm}^{-3}$ ) from bacterial biovolume to biomass. Thus ' $\Delta$ biovolume $_{2 \mu \mathrm{m}} \times f$ ' is $\Delta$ biomass $_{2 \mu \mathrm{m}}(\mu \mathrm{g} \mathrm{C}$ $\mathrm{l}^{-1} \mathrm{~h}^{-1}$ ). We used a value of $f=0.2$ (Kogure \& Koike 1987). Glu-uptake ${ }_{m \text { situ }}$ and Glu-uptake $e_{2 \mu m}\left(\mu \mathrm{g}^{13} \mathrm{C} \mathrm{I}^{-1}\right.$ $\mathrm{h}^{-1}$ ) are $\mathrm{D}-\left[\mathrm{U}-6-{ }^{13} \mathrm{C}\right] \mathrm{glucose}$ uptake by bacterial assemblages per unit time in the in situ and $2 \mu \mathrm{m}$ prescreened incubations, respectively. The measurement results are shown in Table 1. Although dilution of $D$-[U$\left.6-{ }^{13} \mathrm{C}\right]$ glucose by natural labile DOCs might influence ${ }^{13} \mathrm{C}$ uptake by bacterioplankton, for any 1 seawater sample, there would exist some correlation between $\Delta$ biomass $_{2 \mu \mathrm{m}}$ and Glu-uptake ${ }_{2 \mu \mathrm{m}}$. Thus, if the loss rate of fixed ${ }^{13} \mathrm{C}$ derived from glucose is assumed to be similar to that of fixed carbon from natural DOC, the correlation would be the same as that between $\mathrm{BP}_{4 h}$ and

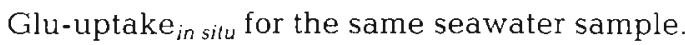

\section{RESULTS}

\section{Environmental variables}

The physical and chemical variables (seawater temperature, $\mathrm{pH}$, dissolved oxygen, and nutrient concentrations) were almost homogeneous at depths of 0 to $5 \mathrm{~m}$ due to the circulation system installed in the mesocosm, which produced a well-mixed surface layer
Table 2. Mean environmental variables (seawater temperature, salinity, $\mathrm{pH}$ and dissolved oxygen) averaged by data sets over depths of 0 to $5 \mathrm{~m}$. Range of variation is for the whole experimental period

\begin{tabular}{|lcc|}
\hline Variable & Average & $\begin{array}{c}\text { Range of } \\
\text { variation }\end{array}$ \\
\hline Seawater temperature $\left({ }^{\circ} \mathrm{C}\right)$ & 28.1 & $(26.8-29.0)$ \\
Salinity $(\%)$ & 32.8 & $(32.6-33.4)$ \\
$\mathrm{pH}$ & 8.2 & $(8.0-8.3)$ \\
Dissolved oxygen $\left(\mathrm{ml} \mathrm{l}^{-1}\right)$ & 7.9 & $(7.0-8.7)$ \\
\hline
\end{tabular}

(Watanabe et al. 1995). Variables other than nutrients are shown in Table 2 as the average for the 0 to $5 \mathrm{~m}$ layer.

Nutrients and autotrophs. The concentrations of nitrate, phosphate and silicate (initial values $=22.1,1.1$ and $7.6 \mu \mathrm{M})$ decreased continually during the early period (Days 0 to 6) (Fig. 1a). In response to the nutrient decrease, the abundance of dinoflagellates, pennate diatoms and centric diatoms (the dominant species being Gymnodinium mikimotoi, Cylindrotheca closterium and Skeletonema costatum, respectively) increased significantly, leading to a blooming phase around Day 6 (Fig. 1b). In contrast, APP abundance decreased continually from Day $0\left(1.0 \times 10^{5} \mathrm{ml}^{-1}\right)$ to Day $6\left(8.8 \times 10^{3} \mathrm{ml}^{-1}\right)$ (Fig. 1c). Also, although ANF increased rapidiy from Day $1\left(1.7 \times 10^{3} \mathrm{ml}^{-1}\right)$ to Day 2 $\left(1.2 \times 10^{4} \mathrm{ml}^{-1}\right)$ (Fig. 1c), they did not continue to increase, but decreased in a similar manner to that of the APP. Chl a (Fig. 1d) increased concomitantly with the total abundance of large phytoplankton, and the maximum value was observed on Day 6 (chl $a=$ $10.3 \mu \mathrm{g} \mathrm{l}^{-1}$ ), implying that the bulk of photosynthesis was being carried out mainly by the large autotrophs in our mesocosm. Changes in net photosynthetic production $\left(\mathrm{PP}_{4 \mathrm{~h}}\right)$ (Fig. 1d) mostly corresponded closely with changes in chl a concentration. The $\mathrm{PP}_{4 \mathrm{~h}}$ was elevated from Day $1\left(62.4 \mathrm{\mu g} \mathrm{C} \mathrm{l}^{-1} 4 \mathrm{~h}^{-1}\right)$ to Day $5(302.8 \mu \mathrm{g}$ $\mathrm{C}^{-1} 4 \mathrm{~h}^{-1}$ ). During the later period (Days 6 to 13 ), the dinoflagellates and pennate diatoms decreased rapidly, but the centric diatoms (mainly $S$. costatum) continued to increase until Day 9 , although nutrient concentrations stayed relatively low (e.g. nitrate $=$ $0.1 \mu \mathrm{M}$, phosphate $=0.08 \mu \mathrm{M}$ and silicate $=0.6 \mu \mathrm{M}$ on Day 7)

\section{Bacterioplankton}

Bacterioplankton density increased steadily from Day $1\left(2.1 \times 10^{6} \mathrm{ml}^{-1}\right)$ to Day $4\left(4.8 \times 10^{6} \mathrm{ml}^{-1}\right)$ (Fig. $2 \mathrm{a}$ ). After a moderate decline on Days 5 and 6 , the density reached a maximum $\left(5.5 \times 10^{6} \mathrm{ml}^{-1}\right)$ on Day 7 and sub- 


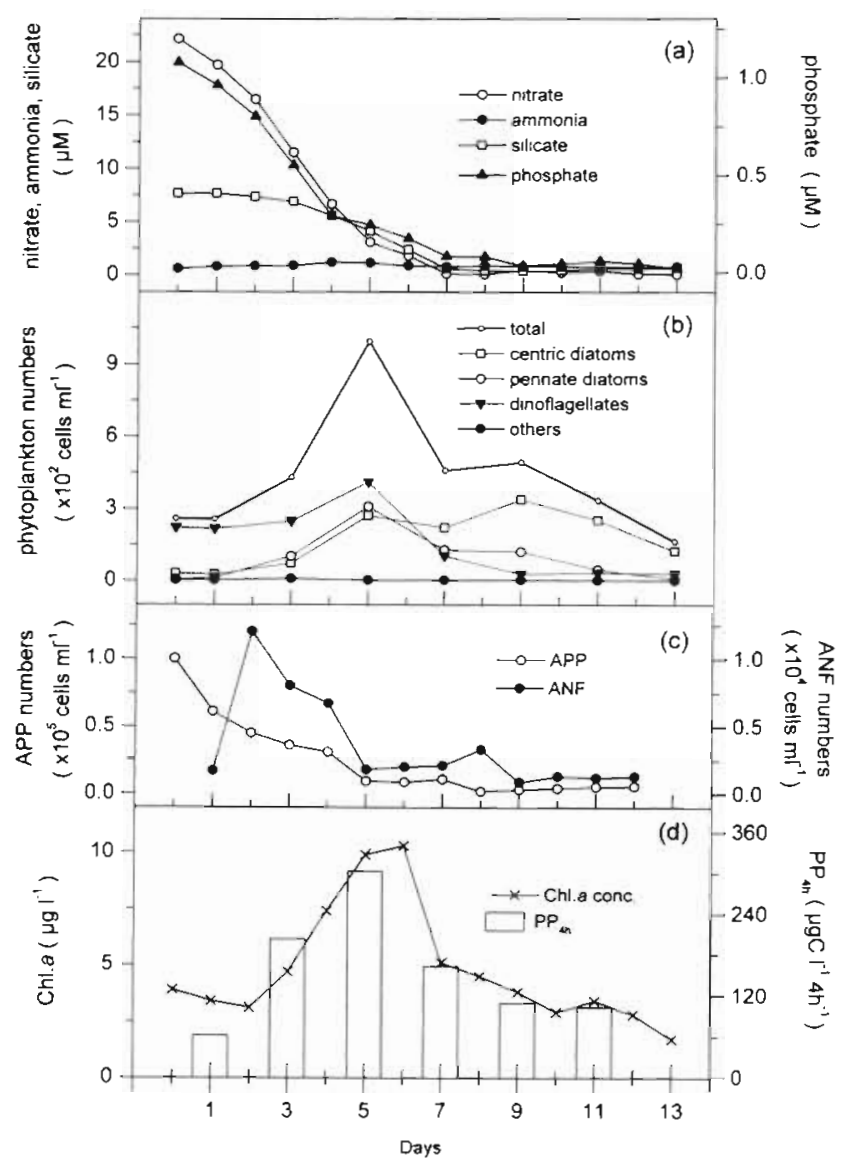

Fig. 1. Changes in: (a) Nutrient concentrations averaged over 0 to $5 \mathrm{~m}$ depth. (b) Phytoplankton numbers (0 to $5 \mathrm{~m}$ depth) determined by light microscopy; 'others' includes Eutreptiella sp., Rhodomonas sp., etc. (c) Phytoplankton numbers $10.5 \mathrm{~m}$ depth) determined by epifluorescence microscopy; APP, autotrophic picoplankton $(0.2$ to $2 \mu \mathrm{m})$, and $A N F$, autotrophic and mixotrophic nanoflagellates (2 to $8 \mu \mathrm{m}$ ), respectively. (d) Chl a concentration and photosynthetic community production in the daytime

sequently decreased gradually, resulting in a minimum $\left(1.8 \times 10^{6} \mathrm{ml}^{-1}\right)$ on Day 13 . The temporal change in $\mathrm{BP}_{4 \mathrm{~h}}$ was not associated with the density of bacterioplankton (Fig. 2a). BP increased from Days $4(16.0 \mu \mathrm{g} \mathrm{C}$ $\left.\mathrm{l}^{-1} 4 \mathrm{~h}^{-1}\right)$ to $8\left(26.8 \mu \mathrm{g} \mathrm{Cl}^{-1} 4 \mathrm{~h}^{-1}\right)$, and then decreased slightly $\left(20.0 \mathrm{\mu g} \mathrm{C}^{-1} 4 \mathrm{~h}^{-1}\right)$ on Day 10.

\section{Heterotrophic protists}

Nano-sized non-fluorescing heterotrophic protists $(2$ to $20 \mu \mathrm{m}$ ) were relatively abundant during the early period (Days 0 to 6) (Fig. 2b,c). The density of HNF in the size range 2 to $8 \mu \mathrm{m}$ reached a maximum $\left(3.5 \times 10^{3}\right.$ $\mathrm{ml}^{-1}$ ) on Day 3 (Fig. 2b). The density of 8 to $20 \mu \mathrm{m}$ nano-sized heterotrophic protists (Fig. 2c), comprising flagellates and small ciliates, showed similar changes to those of HNF and also reached a maximum on Day 3 $\left(1.5 \times 10^{2} \mathrm{ml}^{-1}\right)$.

\section{Microzooplankton}

The micro-sized zooplankton community (20 to $100 \mu \mathrm{m})$ was comprised mainly of copepod nauplii, small appendicularians and tintinnid ciliates (Fig. 2d). A conspicuous temporal change in abundance was observed on Days 6 to 9, due mostly to the tintinnid ciliates (Fig. 2d). They appeared suddenly and reached $1.4 \times 10^{1} \mathrm{ml}^{-1}$ on Day 9 .

\section{Metazooplankton}

The major metazooplankton $(>100 \mu \mathrm{m})$ groups observed in the mesocosm were copepods Paracalanus parvus, Oncaea media, Microsetella norvegica and appendicularians Oikopleura sp. (Fig. 3a). Copepods

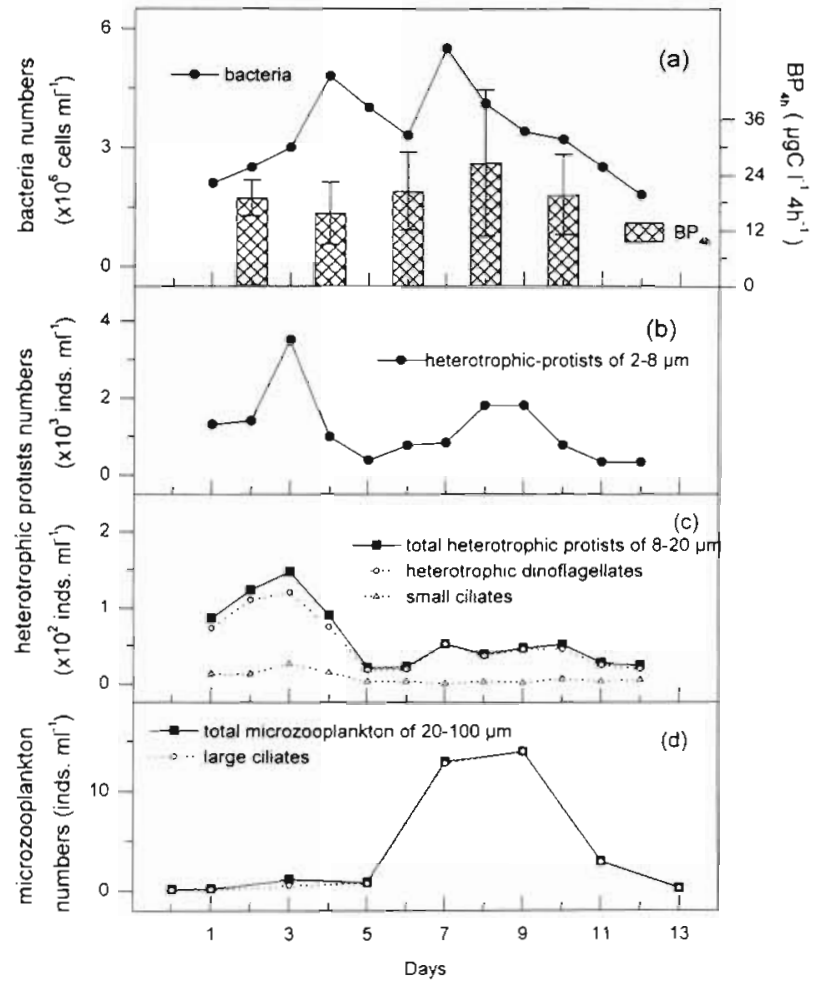

Fig. 2. Changes in: (a) Bacterioplankton numbers and bacterial community production (bars represent standard errors of the means) in the daytime. (b) Nano-sized heterotrophic protist numbers (2 to $8 \mu \mathrm{m})$, comprising mainly heterotrophic nanoflagellates (HNF). (c) Nano-sized protist numbers (8 to $20 \mu \mathrm{m})$, comprising heterotrophic flagellates and small ciliates. (d) Micro-sized protist and metazooplankton numbers (20 to $100 \mu \mathrm{m}$ ), comprising mainly large ciliates (tintinnids) 


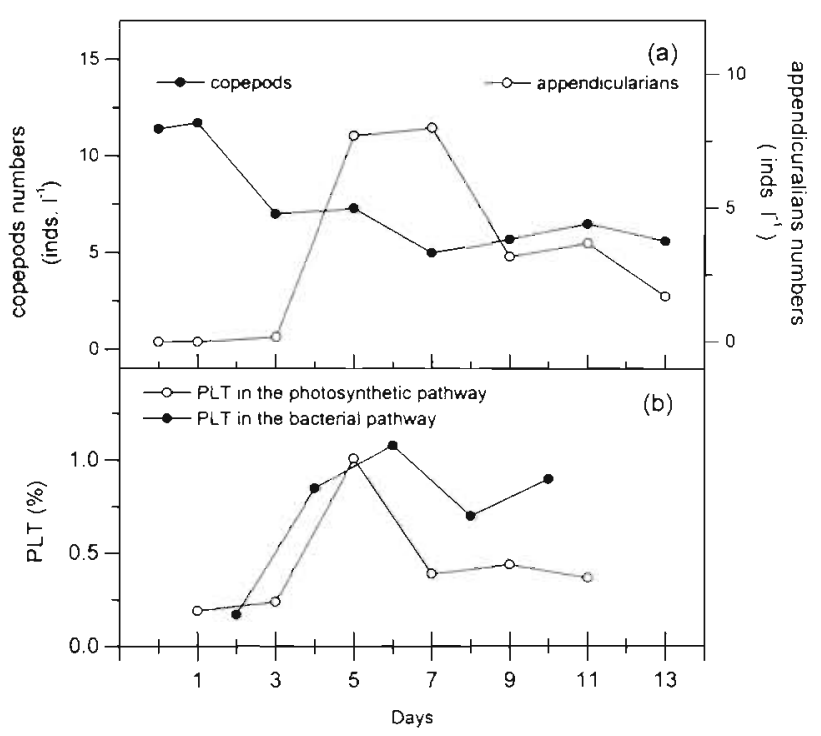

Fig. 3. Changes in: (a) Dominant metazooplankton (copepods and appendicularians) numbers in the $>100 \mu \mathrm{m}$ fractions. (b) Percentage of label transfer (PLT) to metazooplankton in the bacterial and photosynthetic pathways

were observed throughout the whole period. Their density decreased gradually from Days $0\left(11.4 \mathrm{I}^{-1}\right)$ to 7 $\left(5.0 \mathrm{l}^{-1}\right)$ and then remained at 5 to $7 \mathrm{l}^{-1}$ until the end of the period. Appendicularians increased suddenly from Days 3 to 5 and reached $8.01^{-1}$ on Day 7 . After Day 7 . although the abundance of appendicularians decreased to half the maximum, animals with larger body size ( 1 to $2 \mathrm{~mm}$ ) were observed.

\section{Comparison between $\mathrm{BP}_{4 \mathrm{~h}}$ and $\mathrm{PP}_{4 \mathrm{~h}}$}

The ratio of net community production in both pathways $\left(\mathrm{BP}_{4 \mathrm{~h}}: \mathrm{PP}_{4 \mathrm{~h}}\right)$ changed within the range 6 to $21 \%$ (mean, 12\%) (Fig. 4a), which was estimated together with interpolated values between the data points. During the phytoplankton bloom, the ratio was depressed from ca $15 \%$ on Day 2 to $6 \%$ on Day 5 . However, after the bloom $\mathrm{PP}_{4 \mathrm{~h}}$ declined and $\mathrm{BP}_{4 \mathrm{~h}}$ increased, such that the ratio increased, reaching about $21 \%$ on Day 9 .

\section{Relative contribution of two pathways to metazoo- plankton production}

The proportions of label transfer (PLTs) from producers to metazooplankton in the 2 pathways were of a similar magnitude: 0.17 to $1.1 \%$ in the bacterial and 0.19 to $1.0 \%$ in the photosynthetic pathway (Fig. 3b). Thus, the temporal changes in CR (contribution ratio, Fig. 4 b) were apparently related to changes in the ratio of $\mathrm{BP}_{4 \mathrm{~h}}: \mathrm{PP}_{4 \mathrm{~h}}$ rather than to the PLTs; the CRs ranged from ca 6 to $41 \%$ (mean $22 \%$ ) and the $\mathrm{BP}_{4 \mathrm{~h}}$ : $\mathrm{PP}_{4 \mathrm{~h}}$ ratios ranged from ca 6 to $21 \%$ (mean $13 \%$ ).

During the early period (Days 1 to 6 ), the temporal changes in PLT in the 2 pathways showed similar trends (Fig. 3b). The smallest values for PLT in both pathways occurred during the first few days when only copepods were dominant. Subsequently, the PLT values increased concurrently, from $0.17 \%$ on Day 2 to $1.1 \%$ on Day 6 in the bacterial pathway, and from $0.19 \%$ on Day 1 to $1.0 \%$ on Day 5 in the photosynthetic pathway. The temporal changes in both PLTs appeared to correspond to the proliferation of appendicularians. The amounts of carbon transferred to metazooplank-

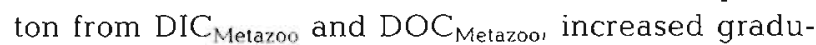
ally and reached maxima on Days 5 and 6, respectively (Fig. 4b). However, the CRs showed a slight decrease from ca $10 \%$ in the copepod-dominant phase to ca $6 \%$ during the rapid increase in appendicularians, because $\mathrm{PP}$ increased more rapidly than $\mathrm{BP}$, which depended on the phytoplankton bloom.

During the later period (Days 7 to 11 ) when the phytoplankton bloom decayed, $\mathrm{BP}_{4 \mathrm{~h}}: \mathrm{PP}_{4 \mathrm{~h}}$ increased, reaching $21 \%$ on Day 9 (Fig. 4 a). The values for PLT in the bacterial pathway, after decreasing over Days 6 to 8

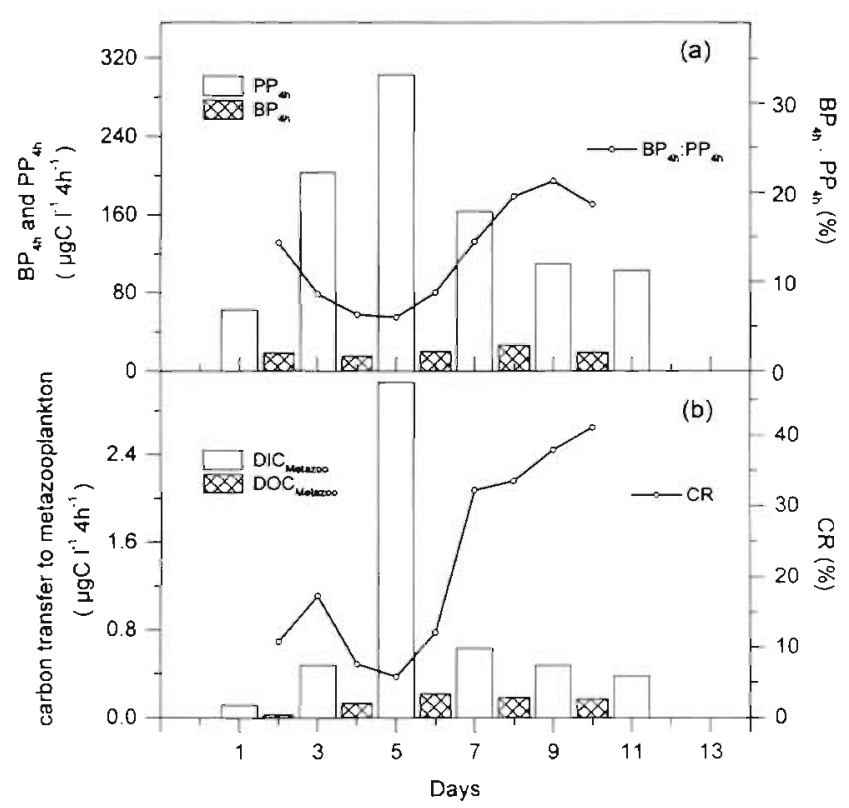

Fig. 4. (a) Comparison of net community production between the bacterial $\left(\mathrm{BP}_{4 \mathrm{~h}}\right)$ and photosynthetic $\left(\mathrm{PP}_{4 \mathrm{~h}}\right)$ carbon pathways, showing the $\mathrm{BP}_{4 \mathrm{~h}}: \mathrm{PP}_{4 \mathrm{~h}}$ ratios. (b) Transfers from dissolved organic (DOC) and inorganic carbon (DIC) to metazooplankton during the $4 \mathrm{~h}$ in situ incubation (DOC Melazoo $_{\text {and }}$ $\mathrm{DIC}_{\text {Metazoo }}$ ) and the relative contribution ratio (CR) of bacterial and photosynthetic production to metazooplankton; temporal changes in $\mathrm{BP}_{4 \mathrm{~h}}: \mathrm{PP}_{4 \mathrm{~h}}$ and $\mathrm{CR}$ were estimated together with interpolated values for each adjacent datum 
(Fig, 3b), increased again, to $0.9 \%$ on Day 10 . However, PLT values in the photosynthetic pathway remained relatively low $(0.37$ to $0.44 \%)$ after their decline on Days 5 to 7 (Fig. 3b). Consequently, the values for CR became higher (ca 30 to $40 \%$ ) and exceeded those for $\mathrm{BP}_{4 \mathrm{~h}}: \mathrm{PP}_{4 \mathrm{~h}}$ (i.e. 15 to $21 \%$ ) over Days 7 to 11 (Fig. 4)

\section{DISCUSSION}

\section{Relative bacterial contribution to metazooplankton production}

The major finding in this study is that the relative carbon transfer in the mesocosm ecosystem from the dissolved state to metazooplankton via the bacterial pathway amounted to $22 \%$ on average (=CR) of that via the photosynthetic pathway. The CRs ranged from 6 to $41 \%$, depending on changes in both $\mathrm{BP}_{4 \mathrm{~h}}: \mathrm{PP}_{4 \mathrm{~h}}$ (range from 6 to $21 \%$ ) and PLT; the latter appeared to be affected strongly by the plankton community structure. When the appendicularians were dominant and the phytoplankton bloom had decayed (i.e. after Day 7 ), large values for $\mathrm{CR}$ of ca 30 to $40 \%$ were found, implying a significant contribution of bacterial production to the metazooplankton assemblages. Relatively low values for $C R$ were found in the copepod-dominant phase (e.g. $C R=c a 10 \%$ on Day 2). Considering that the ratio of net community production $\left(\mathrm{BP}_{4 \mathrm{~h}}: \mathrm{PP}_{4 \mathrm{~h}}\right)$ was ca $15 \%$ at that time, however, the transfer of carbon from bacterial production to metazooplankton was apparently not always inefficient in comparison with the photosynthetic pathway. These results suggest that a trophic pathway based on bacterial production was one of the integral components of the carbon pool for metazooplankton, as opposed to the view that bacterial production is more difficult to transfer to higher trophic organisms than is photosynthetic production.

Net community production and PLT, which are variables of the CR calculation, were strongly influenced by various biological and ecological factors such as nutrient concentration and trophic relationships. The fluctuations in $\mathrm{BP}_{4 \mathrm{~h}}$ and $\mathrm{PP}_{4 \mathrm{~h}}$, or the ratio $\left(\mathrm{BP}_{4 \mathrm{~h}}: \mathrm{PP}_{4 \mathrm{~h}}\right)$, suggest that the addition of macronutrients stimulated photosynthetic production first, and that the organic matter produced then enhanced bacterial productivity after a time lag (Fig. 4a) through various processes of DOC supply (e.g. extracellular release of phytoplankton; see review by Williams 1990). The temporal changes in PLT, the other variable involved in CRs, were probably controlled by the plankton community structure, in particular the dominant species of metazooplankton, their feeding strategies, and the abundance of their prey. In the present study, copepods and appendicularians became sequentially dominant within the mesocosm. In the following discussion, we focus on the relationship between the PLT values and the trophic pathway from bacterioplankton or autotrophs to dominant metazooplankton.

\section{Trophic pathway from pico- or nanoplankton to appendicularians}

Rapid proliferation of appendicularians is a charac teristic event in the mesocosm ecosystem, and has often been observed therein in the Seto Inland Sea, especially in summer (e.g. Uye \& Ichino 1995, Nakamura et al. 1997). Appendicularians have the ability to: (1) filter much larger volumes of water than crustaceans $\mathrm{do}_{i}(2)$ increase rapidly in response to food increase and (3) ingest pico- and namo-sized particles and reject larger particles such as large diatoms and dinoflagellates (e.g. Alldredge \& Madin 1982, King 1982). Azam et al. (1984) studied the incorporation of tritium labeled leucine in a $10 \mathrm{lmicrocosm}$ system into bacteria and various zooplankton (appendicularinas and the other 5 categories). They found that larger amounts of the label accumulated in the appendicularians than those in other zooplankton and suggested that the grazing ability of appendicularians may create a bypass they termed the bacteria to appendicularian shunt. A recent study in a coastal sea reported that their rapid increase led to a marked decrease in the abundance of picoplankton, and that the picoplankton served as a major carbon source for appendicularians (Nakamura et al. 1997).

In the present study, the sudden increase of appendicularians on Days 3 to 5 (Fig. 3a) coincided with a rapid decrease in abundance of nano-sized heterotrophic protists, especially $\operatorname{HNF}$ (2 to $8 \mu \mathrm{m}$ ) (Fig. $2 \mathrm{~b}, \mathrm{c}$ ), while ANF were also tending to decrease (Fig. 1c), suggesting grazing impact by the appendicularians. Of course, the HNF and ANF may have been also ingested by the 8 to $20 \mu \mathrm{m}$ heterotrophic protists at the same time. The abundance of bacterioplankton and APP was also somewhat reduced on Days 4 to 6 (Fig. 2a) and APP were declining continuously until Day 6 (Fig. 1c), even though the abundance of nano-sized heterotrophs had became relatively low (Fig. 2b,c). Further, among the 3 dominant species of phytoplankton, the non-chain-forming Cylindrotheca closterium with ESD ca $5 \mu \mathrm{m}$ declined markedly from 220 cells $\mathrm{ml}^{-1}$ on Day 5 to 4 cells $\mathrm{ml}^{-1}$ on Day 7 , but the other 2 dominant species (the chain-forming centric diatom Skeletonema costatum and the autotrophic dinoflagellate Gymnodinium mikimotoi $[\mathrm{ESD}=\mathrm{ca} 11$ to $27 \mu \mathrm{m}$ ) did not decrease markedly during this period (Fig. 1a). These results show that only small 
phytoplankton species decreased in abundance during the dominant phase of the appendicularians. In view also of the fact that small autotrophs can use nutrients more efficiently than can larger autotrophs, the decreases in only APP. ANF and small pennate diatoms would indicate a selective grazing impact on small autotrophs. Therefore, the changes in the abundance of small autotrophs on Days 3 to 7 are probably due to the appendicularians' removal of pico- and nano plankton simultaneously.

The presence of appendicularians with such grazing activity created a direct trophic pathway from picoplankton to metazooplankton in the mesocosm. Their presence, furthermore, might diminish respiratory carbon loss from heterotrophic intermediates between picoplankton and metazooplankton by removing the intermediates themselves, and subsequently increase the chances of direct grazing of picoplankton by the appendicularians.

In the bacterial pathway, this feeding strategy may have increased the efficiency of bacterial carbon transfer to metazooplankton. This conclusion is supported by the increase in PLTs (0.7 to $1.1 \%$ ) after Day 4, when the appendicularians appeared (Fig. $3 b$ ), implying that bacterial production was transferred efficiently to the $>100 \mu \mathrm{m}$ particles.

In the photosynthetic pathway, however, a high PLT occurred only on Day 5 (Fig. 3b), when the small pennate diatom Cylindrotheca closterium was highly abundant. On Day 3 and after Day 7 , relatively lower PLTs were found (Fig. 3b). On Day 3, this might be because although the ANF and APP would have been ingested by the appendicularians as well as the bacteria and HNF, their photosynthetic production would be less than that of the other, larger dominant phytoplankton, owing to the smaller cell volumes of ANF and APP. The relatively low photosynthetic production by ANF and APP also would be reflected in the total chl a concentration and PP (Fig. 1d), which were increasing around Day 3 , in spite of the concurrent decrease in ANF and APP. Consequently, the PLT in the photosynthetic pathway would not show a conspicuous increase on Day 3. As to the PLT results after Day 7 , the occurrence of 20 to $100 \mu \mathrm{m}$ tintinnid ciliates (Fig. 2d) may have had a strong influence on the fate of photosynthetic production. The occurrence of the ciliates followed the phytoplankton bloom (Figs. 1b \& 2d) that may have supported them (e.g. Capriulo \& Carpenter 1980). Tintinnid ciliates were responsible for the decay of a red tide of the autotrophic dinoflagellate Gymnodinium mikimotoi in a coastal sea area, and then became abundant (Nakamura et al. 1995, 1996). If large ciliates feed mainly on nanoplankton and opportunistically on picoplankton (e.g. Sherr et al. 1989), they may exploit small phytoplankton species on which the appendicularians may also feed. Thus, the appendicularians and ciliates may compete with each other as herbivores, which might also have been a factor in the decrease of PLT in the photosynthetic pathway on Days 7 to 9 .

These changes in PLI in both pathways, which can be explained by means of trophic relationships, were major factors leading to the relative high contribution of bacterial production to the metazooplankton community (CR), increasing from $6 \%$ around Day 5 to $30-40 \%$ around Day 9.

With respect to population dynamics in the mesocosm, the occurrence of appendicularians may disturb the trophic interactions between pico- and nano-sized organisms in the microbial food web, such as that between bacteria and HNF. The appendicularians may have a role in breaking the microbial food pathways, as Deibel \& Lee (1992) suggested. In the present study, the organisms in the bacterial pathway appeared to be influenced greatly by them. However, considering that the lowest CR (ca $6 \%$ ) occurred just after the rapid increase in appendicularians, their occurrence was apparently triggered primarily by autotrophs. Large values for CR (ca 30 to $40 \%$ ) were observed only after the small phytoplankton had been exhausted. Therefore, we suggest that bacterial products are food resources for appendicularians, together with photosynthetic products, and that the importance of bacterial products may increase when the availability of autotrophs declines.

\section{Similarity of complex photosynthetic and bacterial pathways to copepods}

During the phase when copepods dominated the metazooplankton assemblage (Days 0 to 3 ), the contribution of bacterial production was relatively small (e.g. $\mathrm{CR}=\mathrm{Ca} 10 \%$ on Day 2) compared with that during the appendicularian-dominant phase. However, the values for PLT in the bacterial and photosynthetic pathways were quite similar to each other; $0.19 \%$ (Day 1) in the photosynthetic and $0.17 \%$ (Day 2) in the bacterial pathway (Fig. 3), and the CR values (e.g. ca $10 \%$ on Day 2) were similar to those of the ratio of net community production (BP:PP $=$ ca $15 \%$ ). The similarity in PLT values in the 2 pathways suggests that the potential carbon transfer from bacterial production to copepods was sometimes equal to that from photosynthetic production in the mesocosm.

Copepods are incapable of ingesting pico-sized particles directly (e.g. Nival \& Nival 1976). Thus, they would be able to exploit autotrophic picoplankton and bacterioplankton only via intermediaries such as heterotrophic protists (e.g. Sherr et al. 1986). In the pre- 
sent study, the steady decrease of APP, in contrast to the increases in larger autotrophs, until the proliferation of the appendicularians (Fig. 1b,c) would imply strong grazing impact on the APP by heterotrophic protists such as HNF (e.g. Weisse 1991), which were gradually becoming abundant before Day 3 (Fig. 2b,c). Hence, there might exist carbon pathways to the copepods both from the APP and from bacterioplankton via the microbial loop during this period.

Pico-sized organisms would be an exclusive source of organic carbon in the bacterial pathway, while nano- and micro-sized autotrophs would be sources of photosynthetic production to copepods directly via the photosynthetic pathway. Considering that the rapid decrease of APP abundance (Fig. 1c) was not always reflected in chl a concentration (Fig. 1d), much of the photosynthetic production on Days 0 to 3 might have been from larger phytoplankton, such as Gymnodinium mikimotoi (Fig. 1b). If the copepods had ingested the G. mikimotoi directly and as a main source of photosynthetic production, the PLT in the photosynthetic pathway on Day 2 would have risen more in comparison with the PLT in the bacterial pathway on Day 1 (Fig. 3b), because such a direct trophic pathway is more efficient than the other routes, which have more than 2 trophic steps, like that from bacterioplankton to copepods. The similarity in magnitude of PLTs in the 2 pathways around Day 2 (Fig. 3b) may be explained by the fact, demonstrated by Uye \& Taka-

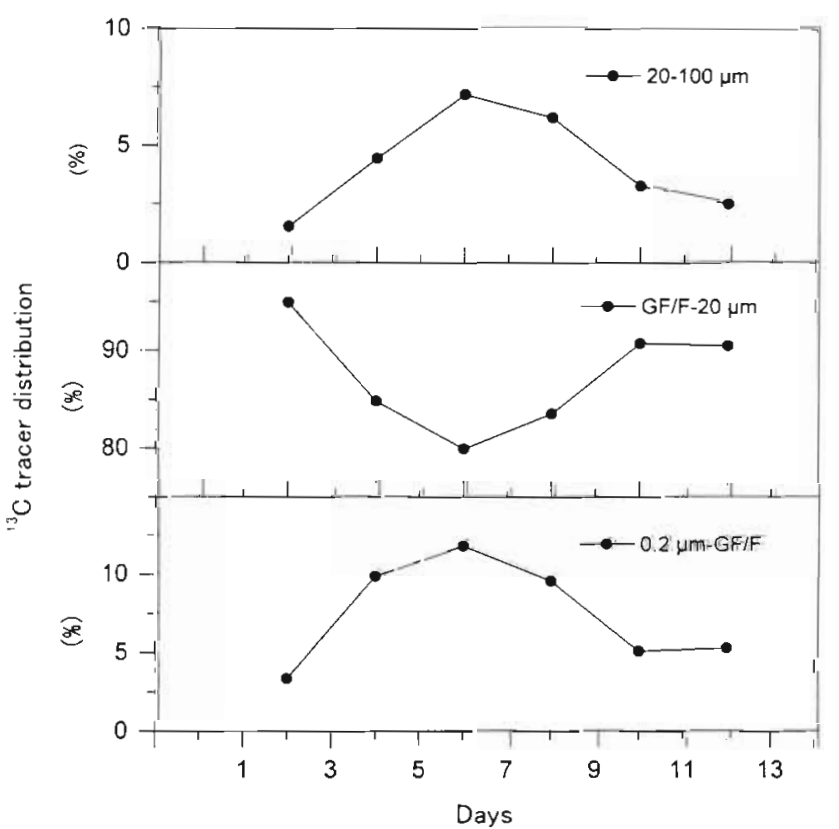

Fig. 5. Changes in percentages of ${ }^{13} \mathrm{C}$ retained in the $<100 \mu \mathrm{m}$ fractions (prey fractions for metazooplankton) after $4 \mathrm{~h}$ in situ incubation in the bacterial carbon pathway matsu (1990), that $G$. nagasakiense (= G. mikimoton) is almost entirely rejected by the copepod Acartia omorii due to deterrent chemical compounds produced by the phytoplankton. Some other dinoflagellate species also produce chemical substances that induce avoidance behavior in copepods (see review by Kleppel 1993). Thus, we presume that the direct ingestion impact on G. mikimotoi by the dominant copepods in the mesocosm was not high, resulting in the low PLT in the photosynthetic pathway. As a consequence, the significance of the APP, ANF and other mixotrophic protists as primary producers for the copepods' diet was relatively greater. Further, the abundant nano-sized heterotrophic protists (Fig. 2c) might ingest such autotrophs, and mediate the carbon transfer to copepods, as many studies have suggested (see review by Sherr \& Sherr 1994). From the above, we suggest that the photosynthetic pathway to copepods often includes more than 2 trophic steps (e.g. $[\mathrm{APP} \rightarrow]$ ANF $\rightarrow$ [heterotrophic protists] $\rightarrow$ copepods) in the mesocosm, which are similar to the bacterial pathway (bacteria $\rightarrow$ $\mathrm{HNF} \rightarrow$ [heterotrophic protists] $\rightarrow$ copepods)

\section{Carbon transfer and retention on bacterivores}

The transfer of bacterial production to nano-sized bacterivores was likely to be reflected in the ${ }^{13} \mathrm{C}$ distribution in the $<100 \mu \mathrm{m}$ fractions in the bacterial pathway experiment (Fig, 5). The percentages of ${ }^{13} \mathrm{C}$ retained in the GF/F-20 $\mu \mathrm{m}$ fraction was highest on Day 2 and dropped towards Day 6. Conversely, percentages of ${ }^{13} \mathrm{C}$ retained in the $0.2 \mu \mathrm{m}-\mathrm{GF} / \mathrm{F}$ fraction increased from Days 2 to 6 . These changes appear to have been caused by changes in abundance of the nano-sized heterotrophic protists, and imply that a higher proportion of bacterial production had been transferred to larger particles through bactivorous activity of nano-sized protists around Day 2 than around Day 6. Of course, this observation cannot be considered as direct evidence for the transfer of bacterial production to protists, because the GF/F filter (pore size ca $0.7 \mu \mathrm{m}$ ) would retain a high proportion of the bacterioplankton (e.g. more than $50 \%$ of total bacterial abundance; Nagata 1988) in addition to most of the protists. But we also observed similar temporal changes in ${ }^{13} \mathrm{C}$ distribution between the $0.2 \mu \mathrm{m}$-toGF/C and GF/C-to-20 $\mu \mathrm{m}$ fractions in a 1991 mesocosm experiment (Koshikawa et al. 1996). Briefly, we suggest that bacterial production during the $4 \mathrm{~h}$ incubations was ingested by and transferred rapidly to the nano-sized bacterivores and a high proportion was retained in their bodies.

Considering the availability of bacterial carbon to the copepods, this result seems to contain 2 opposing 
aspects. On the one hand, there was evidently the possibility of the copepods to receiving bacterial production via the nano-sized heterotrophs during the $4 \mathrm{~h}$ incubations. On the other hand, the copepods would have been able to use only a part of the bacterial production, because some of it was retained in the nanosized protists and probably some was lost through their respiration.

${ }^{13} \mathrm{C}$ distribution cannot be used to analyze the photosynthetic pathway because the autotrophic producers and consumers are mostly in the same size fraction (GF/F to $20 \mu \mathrm{m}$ ). But considering the trophic relationships in the photosynthetic pathway mentioned in the previous paragraph, we presume that the potential of carbon transfer from autotrophic producers to copepods was similar to that via the bacterial pathway, resulting in similar and low values of PLT in the 2 pathways and in similar ratios of CR to BP:PP during the copepod-dominant period in the mesocosm.

\section{Similar low PLTs in the two pathways}

Throughout our mesocosm experiment, the PLTs in the 2 pathways were of similar magnitude 10.17 to $1.1 \%$ in the bacterial and 0.19 to $1.0 \%$ in the photosynthetic pathway (Fig. $3 \mathrm{~b}$ ). This result was similar to our previous mesocosm study, in which copepods or doliolids were the abundant metazooplankton: PLTs of 0.09 to $2.7 \%$ in the photosynthetic and 0.22 to $1.5 \%$ in the bacterial pathway (Koshikawa et al. 1996). With regard to PLT in the bacterial pathway, Parsons et al. (1980) performed similar bottle incubations for $6 \mathrm{~h}$, enriched with ${ }^{14} \mathrm{C}$ glucose, in an enclosure in Saanich Inlet, Canada. They reported slightly higher values for percentage ${ }^{14} \mathrm{C}$ transfer to $>100 \mu \mathrm{m}$ fractions (PLTs $=$ ca 3 to $4 \%$, calculated from the published data) in the eutrophic site, where jellyfish and copepods were present in the metazoa. We expect that low and similar values of PLTs in the 2 pathways might be common in eutrophic environments.

\section{CONCLUSION}

The fate of bacterial and photosynthetic production as sinks or links cannot be discussed only from the low absolute values of PLTs. However, our results indicate that bacterial production was definitely transferred to metazooplankton to a similar extent to that of photosynthetic production, and played a significant role as one of the food sources for metazooplankton. Consequently, metazooplankton is likely to make use of both production sources, depending mostly on their community production ratios in the coastal environment.
Acknowledgements. We are grateful to Dr Y Nakamura (National Institute for Environmental Studies), Dr T Nagata (Ocean Research Institute, University of Tokyo) and Dr K. Kato (Shinshu University) for comments on the manuscript, and Ms M. Kajiwara for technical assistance. We thank 4 anonymous reviewers for their constructive criticisms of an earlier version of the manuscript.

\section{LITERATURE CITED}

Alldredge AL، Madin LP (1982) Pelagic tunicates: unique herbivores in the marine plankton. BioScience 32:655-663

Altabet MA (1990) Organic C, N, and stable isotopic composition of particulate matter collected on glass-fiber and aluminum oxide filters. Limnol Oceanogr 35:902-909

Azam F. Hodson RE (1977) Size distribution and activity of marine microheterotrophs. Limnol Oceanogr 22:492-501

Azam F, Fenchel I, Field JG, Gray JS, Meyer-Reil LA, Thingstad $F$ (1983) The ecological role of water-column microbes in the sea. Mar Ecol Prog Ser 10:257-263

Azam F, Cowles T, Banse K, Osborn J, Harrison PJ, Kennedy $C$ (1984) Free-living pelagic bacterioplankton: sink or link in a marine food web? EOS 45:926

Capriulo GM, Carpenter EJ (1980) Grazing by 35 to $202 \mathrm{~mm}$ microzooplankton in Long Island Sound. Mar Biol 56:319-326

Cole JJ, Findlay S, Pace ML (1988) Bacterial production in fresh and saltwater ecosystems: a cross-system overview. Mar Ecol Prog Ser 43:1-10

Deibel D, Lee SH (1992) Retention efficiency of sub-micrometer particles by the pharyngeal filter of the pelagic tunicate Oikopleura vanhoeffeni. Mar Ecol Prog Ser 81:25-30

Ducklow HW, Purdie DA, Williams PJLeB, Davies JM (1986) Bacterioplankton: a sink for carbon in coastal marine plankton community. Science 232:865-867

Gifford DJ, Dagg MJ (1991) The microzooplankton-mesozooplankton link: consumption of planktonic protozoa by the calanoid copepods Acartia tonsa Dana and Neocalanus plunchrus Murukawa. Mar Microb Food Webs 5: $161-177$

Hama T, Miyazaki T, Ogawa Y, Iwakuma T, Takahashi M, Otsuki A, Ichimura S (1983) Measurement of photosynthetic production of marine phytoplankton population using a stable ${ }^{13} \mathrm{C}$ isotope. Mar Biol 73:31-36

King KR (1982) The population biology of the larvacean Oikopleura dioica in enclosed water columns. In: Grice GD, Reeve MR (eds) Marine mesocosms. Springer-Verlag, New York, p $341-351$

Kleppel GS (1993) On the diets of calanoid copepods. Mar Ecol Prog Ser 99:183-195

Kogure K, Koike l (1987) Particle counter determination of bacterial biomass in seawater. Appl Environ Microbiol 53: $274-277$

Kohata K, Watanabe M. Yamanaka K (1991) Highly sensitive determination of photosynthetic pigments in marine in situ samples by high-performance liquid chromatography. J Chromatogr 558:131-140

Koshikawa H, Harada S, Watanabe M, Sato K, Akehata T (1996) Relative contribution of bacterial and photosynthetic production to metazooplankton as carbon sources. J Plankton Res 18:2269-2281

Mopper K, Dawson R, Liebezeit G, Ittekkot V (1980) The monosaccharide spectra of natural waters. Mar Chem 10: $55-56$

Nagata T (1988) The microflagellate-picoplankton food linkage in the water column of Lake Biwa. Limnol Oceanogr 33:504-517 
Nakamura Y, Suzuki S, Hiromi J (1995) Population dynamics of heterotrophic dinoflagellates during a Gymnodinium mikimotoi red tide in the Seto Inland Sea. Mar Ecol Prog Ser 125:269-277

Nakamura Y, Suzuki S, Hiromi J (1996) Development and collapse of a Gymnodinium mikimotoi red tide in the Seto Inland Sea. Aquat Microb Ecol 10:131-137

Nakamura Y, Suzuki K, Suzuki S, Hiromi J (1997) Production of Oikopleura dioica (Appendicularia) following a picoplankton 'bloom' in eutrophic coastal area. J Plankton Res 19:113-124

Nival P, Nival S (1976) Particle retention efficiencies of an herbivorous copepod, Acartia clausi (adult and copepodite stages): effects on grazing. Limnol Oceanogr 21:24-38

Parsons TR, Albright LJ, Whitney F, Wong CS, Williams PJLeB, (1980) The effect of glucose on the productivity of seawater: an experimental approaching controlled ecosystems. Mar Environ Res 4:229-242

Porter KG, Feig YS (1980) The use of DAPI for identifying and counting aquatic microflora. Limnol Oceanogr 25:943-948

Sanders RW, Wickham SA (1993) Planktonic protozoa and metazoa: predation, food quality and population control. Mar Microb Food Webs 7:197-223

Sherr EB, Sherr BF (1988) Role of microbes in pelagic food webs: a revised concept. Limnol Oceanogr 33:1225-1227

Sherr EB, Sherr BF (1994) Bacterivory and herbivory; key roles of phagotrophic protists in pelagic food webs. Microb Ecol 28:223-235

Sherr EB, Sherr BF, Paffenhöfer GA (1986) Phagotrophic protozod as food for metazoans: a 'missing' link in marine pelagic food webs? Mar Microb Food Webs 1:60-80

Sherr EB, Rassoulzadegan F. Sherr BF (1.989) Bacterivory by pelagic choreotrichous ciliates in coastal waters of the $N W$ Mediterranean Sea. Mar Ecol Prog Ser 55:235-240

Stoecker DK, Capuzzo JM (1990) Predation on protozoa: its importance to zooplankton. J Plankton Res 12:891-908

Thompson PA, Calvert SE (1994) Carbon-isotope fractiona-

Editorial responsibility: Otto Kinne (Editor),

Oldendorf/Luhe, Germany tion by a marine diatom: the influence of irradiance, daylength, $\mathrm{pH}$ and nitrogen source. Limnol Oceanogr 39 : $1835-1844$

Uye $S_{1}$ Ichino S (1995) Seasonal variations in abundance, size composition, biomass and production rate of Oikopleura dioica (Fol) (Tunicata: Appendicularia) in a temperate eutrophic inlet. J Exp Mar Biol Ecol 189:1-11

Uye S, Takamatsu K (1990) Feeding interactions between planktonic copepods and red-tide flagellates from Japanese coastal waters. Mar Ecol Prog Ser 59:97-107

Verity PG, Sieracki ME (1993) Use of color image analysis and epifluorescence microscopy to measure plankton biomass. In: Kemp PF, Sherr BF, Sherr EB, Cole JJ (eds) Handbook of methods in aquatic microbial ecology. Lewis Publishers, Boca Raton, FL, p 309-318

Viles CL, Sieracki ME (1992) Measurement of marine picoplankton cell size by using a cooled, charge-coupled device camera with image-analyzed fluorescence microscopy. Appl Environ Microbiol 58:584-592

Watanabe M, Kohata K, Kimura T, Takamatsu T, Yamaguchi S, Ioriya $\mathrm{T}$ (1995) Generation of a Chattonella antiqua bloom by imposing a shallow nutricline in a mesocosm. Limnol Oceanogr 40:1447-1460

Weisse T (1991) The annual cycle of heterotrophic freshwater nanoflagellates: role of bottom-up versus top-down control. J Plankton Res 13:167-185

Wikner J, Hagström \& (1988) Evidence for a tightly coupled nanoplanktonic predator-prey link regulating the bacterivores in the marine environment. Mar Ecol Prog Ser 50: $137-145$

Williams PJLeB (1990) The importance of losses during microbial growth: commentary on the physiology, measurement and ecology of the release of dissolved organic material. Mar Microb Food Webs 4:175-206

Wylie JL, Curne DJ (1991) The relative importance of bacteria and algae as food sources for crustacean zooplankton. Limnol Oceanogr 36:708-728

Submitted: February 4, 1997; Accepted: April 9, 1999

Proofs received from author(s): August 12, 1999 